\title{
Analisis Efektivitas Penerapan Mobile Application KAI Access Di PT. Kereta Api Indonesia (Persero)
}

\author{
Benny Agustian ${ }^{a}$, Deni Nurdyana Hadimin ${ }^{b}$ \\ a ,b Universitas Sangga Buana YPKP, Kota Bandung \\ bennyaagus@gmail.com
}

\begin{abstract}
Abstrak
Suatu perusahaan akan berupaya meningkatkan kualitas pelayanan untuk masyarakat. Salah satu perusahaan yang sudah mengembangkan beberapa inovasi yaitu PT. Kereta Api Indonesia (Persero) dengan menciptakan mobile application KAI Access, yaitu aplikasi yang digunakan untuk membeli tiket secara online tanpa harus mengantri di loket stasiun. Oleh karena itu tujuan penelitian ini adalah untuk mengetahui efektivitas penerapan mobile application KAI Access di PT. Kereta Api Indonesia (Persero) yang mengacu pada empat variabel evaluasi yaitu kualitas informasi, kualitas pelayanan, penggunaan dan kepuasan pengguna. Penelitian ini merupakan penelitian deskriptif kualitatif bertujuan untuk mengetahui kualitas informasi, kualitas layanan, penggunaan dan kepuasan pengguna tanpa membuat suatu perbandingan atau menghubungkan dengan variabel lain. Data yang digunakan dalam penelitian ini adalah wawancara dengan informan kunci dari PT. Kereta Api Indonesia (Persero), wawancara dengan lima orang pengguna dari aplikasi KAI Access serta kuesioner yang dilakukan dengan jumlah 42 responden sebagai data pendukung untuk penelitian ini. Hasil penelitian menunjukkan bahwa efektivitas penerapan mobile application KAI Access di PT. Kereta Api Indonesia (Persero) dapat dikatakan sangat efektif. Hal ini dapat dilihat dari hasil penelitian setiap variabel evaluasi, yaitu kualitas informasi yang sudah akurat, relevan dan lengkap, kualitas layanan yang sudah cepat tanggap dan empati, penggunaan yang sudah mudah untuk penggunaan sehari-hari, serta kepuasan pengguna yang efisien, efektiv dan puas.
\end{abstract}

Kata Kunci : Efektivitas, Mobile Application KAI Access, Kepuasan Pengguna.

\section{Abstract}

A company will try to improve the quality of service for the community. A company that has developed several innovations PT. Kereta Api Indonesia (Persero) by creating the KAI Access mobile application, which is an application that is used to buy tickets online without having to queue at the station counter. Therefore, the purpose of this research is to determine the effectiveness of the application of the KAI Access mobile application at PT. Kereta Api Indonesia (Persero) which refers to four evaluation variables, namely information quality, service quality, usage and user satisfaction. This research is a qualitative descriptive research which aims to determine the quality of information, service quality, usage and user satisfaction without making a comparison or linking with other variables. The data used in this research are interviews with key informants from PT. Kereta Api Indonesia (Persero), interviews with five users of the KAI Access application and a questionnaire conducted with a total of 42 respondents as supporting data for this research. The results showed that the effectiveness of the application of the KAI Access mobile application at PT. Kereta Api Indonesia (Persero) can be said to be very effective. This can be seen from the research results of each evaluation variable, namely the quality of information that is accurate, relevant and complete, the quality of service that is responsive and empathetic, easy use for daily use, and efficient, effective and satisfied user satisfaction.

Keywords: Effectiveness, Mobile Application KAI Acces, User Satisfied.

\section{PENDAHULUAN}

Bisnis adalah suatu kegiatan manusia yang bertujuan untuk menghasilkan keuntungan dengan memproduksi dan menjual suatu produk atau jasa. Konsep bisnis ialah ide dunfamental yang ada di balik sebuah bisnis, berdasarkan konsep tersebut seorang pengusaha dapat mengembangkan model bisnis, rencana bisnis serta visi dan misi dari sebuah bisnis. Bisnis pada jaman sekarang telah mengalami perkembangan baik dalam teknologi pada 
proses produksi, sistem informasi dan pembayaran ataupun pemasaran. Bisnis pada jaman sekarangada kaitannya dengan perkembangan industri yang di mana sering disinggung dengan istilah revolusi industri 4.0. perkembangan teknologi informasi saat ini tentu berawal dari kemajuan di bidang komputerisasi. Penggunaan komputer pada masa awal hanya sekedar untuk menulis, membuat grafik dan gambar serta alat menyimpan data, namun kini komputer dan internet telah memiliki manfaat yang berbeda.

Tabel 1. 1

Era Perkembangan Komputerisasi

\begin{tabular}{|c|c|c|c|}
\hline No & Periode Era & Tahun & $\begin{array}{c}\text { Arah } \\
\text { Manfaat }\end{array}$ \\
\hline 1 & Era Komputerisasi & 1960-an & $\begin{array}{l}\text { Pemakaian } \\
\text { komputer } \\
\text { untuk } \\
\text { peningkatan } \\
\text { efisiensi }\end{array}$ \\
\hline 2 & $\begin{array}{l}\text { Era Teknologi } \\
\text { Informasi }\end{array}$ & 1970-an & $\begin{array}{l}\text { Kegunaan } \\
\text { komputer } \\
\text { bukan hanya } \\
\text { untuk } \\
\text { meningkatkan } \\
\text { efisiensi, } \\
\text { tetapi juga } \\
\text { untuk } \\
\text { mendukung } \\
\text { terjadinya } \\
\text { proses kerja } \\
\text { yang lebih } \\
\text { efektif. }\end{array}$ \\
\hline 3 & $\begin{array}{l}\text { Era Globalisasi } \\
\text { Informasi }\end{array}$ & 1989-an & $\begin{array}{l}\text { Komputer } \\
\text { sebagai media } \\
\text { informasi. }\end{array}$ \\
\hline 4 & $\begin{array}{ll}\text { Era } & \text { Sistem } \\
\text { Informasi } & \end{array}$ & 1990-an & $\begin{array}{l}\text { Komputer } \\
\text { dilakukan } \\
\text { untuk } \\
\text { melakukan } \\
\text { manajemen } \\
\text { perubahan } \\
\text { (Management } \\
\text { Change) }\end{array}$ \\
\hline
\end{tabular}

Sumber : Kholil, Syukur (Ed), Teori Komunikasi Massa. 2011

Perkembangan teknologi sistem informasi dan perkembangan internet mendorong adanya revolusi industri 4.0 di mana semua sistem dijalankan dengan berbasis internet atau lebih dikenal dengan istilah internet of things (IoT). Revolusi Industri 4.0 telah membawa perubahan signifikan terhadap berbagai sendi kehidupan manusia dengan nyata dapat mencermati bagaimana perubahan tersebut menjadi fenomena dahsyat yang tidak dapat dibendung, sepanjang tahun 2018 perusahaanperusahaan dunia dan juga di Indonesia berlomba-lomba dalam melakukan inovasi untuk memenangkan persaingan pasar di tengah semakin ketatnya kompetisi.

Inovasi yang dilakukan diantaranya dilakukan dengan strategi trasnformasi digital, melakukan perubahan menyeluruh atas setiap proses, kompetensi dan model bisnis dengan implementasi teknologi digital, sejalan dengan rekomendasi berbagai Lembaga riset global yang menjadikan transformasi digital sebagai pengurusutamaan organisasi dalam memenangkan persaingan global. Indonesia memiliki pasar yang besar untuk sebuah dan ushaa. Di era modern, persaingan bisnis menjadi lebih beragam, bukan hanya untuk bisnis konvensional melainkan juga merambah pada bisnis berbasis teknologi.

Berkembangnya bisnis berbasis teknologi diiringi dengan jumlah penduduk dan pengguna internet di Indonesia yang mencapai 215 juta pengguna menjadikan Indonesia sebagai negara dnegan nilai valuasi ekonomi digital terbesar di Asia Tenggara dengan total valuasi sebesar US\$130 juta pada tahun 2019, bahkan pemerintah menargetkan valuasi ekonomi digital Indonesia mencapai US\$150 juta pada tahun 2025 (Kompas.com, Pertiwi, 2019). Data lain yang disajikan dalam lama katadata.com menunjukkan angka yang lebih atraktif di mana potensi ekonomi digital Indonesia tahun 2025 akan berkembang dua kali lipat dari valuasi tahun 2019. Pada sektor e-commerce atau perdagangan online valuasi ekonominya diperkirakan akan mencapai US\$82 juta pada tahun 2025 di mana pada tahun 2019 hanya sebesar US\$21 juta. Di sisi lain, sektor travel online akan tumbuh US\$15 juta dari US\$10 juta pada tahun 2019 menjadi US\$25 juta pada tahun 2025, serta pada sektor transportasi online akan tumbuh US\$12 juta dari US\$6 juta pada tahun 2019 menjadi US\$18 juta pada tahun 2025 (katadata.com, 2019).

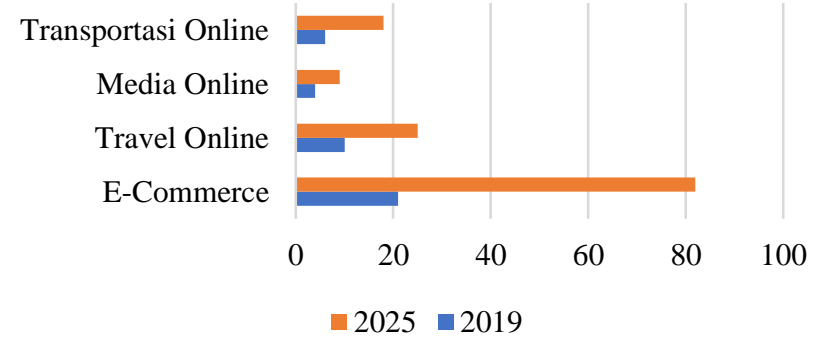

Gambar 1. 1

Perbandingan Valuasi Ekonomi Digital Indonesia 2019 dan 2025 Sumber : Katadata.co.id

Atas dasar potensi ekonomi digital yang terus berkembang ini, banyak perusahaan yang mulai mengubah pola bisnisnya dari bisnis konvensional menjadi bisnis berbasis teknologi dan internet. Salah satunya adalah PT. Kereta Api Indonesia (Persero).

PT. Kereta Api Indonesia (Persero) merupakan Badan Usaha Milik Negara (BUMN) yang membawahi jasa pelayanan transportasi kereta api. PT. Kereta Api Indonesia (Persero) melayani jasa angkutan kereta api penumpang dan barang.

Dalam upaya mempertahankan persaingan bisnis dan mendapatkan lebih banyak pelanggan, PT. Kereta ApiIndonesia (Persero) meluncurkan produk aplikasi untuk pemesanan dan pembelian tiket yaitu aplikasi KAI Access 
sebagai salah satu motivasi PT. Kereta Api Indonesia (Persero) untuk memudahkan para pelanggan melakukan pemesanan tiket perjalanan kereta api.

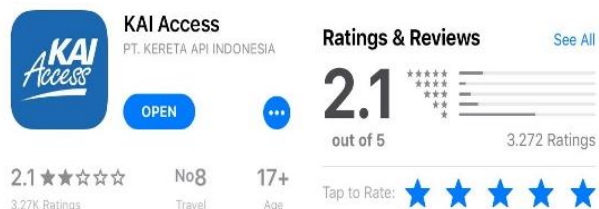

Gambar 1.2

Ratting Aplikasi di Appstore

Sumber : AppStore Apple (18 Maret 2021)

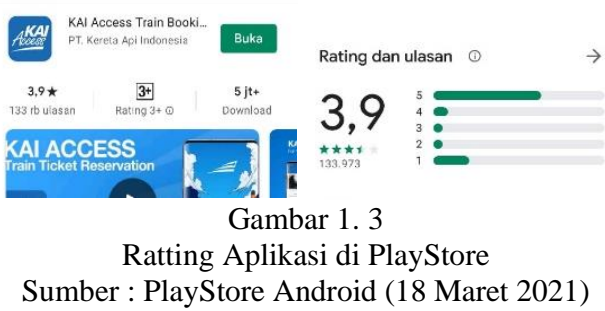

Saat ini aplikasi KAI Access pertanggal 18 Maret 2021 memiliki rating 3,9/5 di Google PlayStore Android dan rating 2,1/5 di AppStore iOS. Hal ini menunjukkan perlu adanya hal yang masih perlu diperbaiki untuk mendapatkan rating yang lebih tinggi sebagai bagian dari penilaian konsumen terhadap aplikasi KAI Access. Oleh karena itu, peneliti bermaksud melakukan penelitian untuk menilai sejauh mana aplikasi KAI Access memberikan efektivitas kepada pelanggan.

Berdasarkan latar belakang dan fokus penelitian yang telah dijelaskan, maka rumusan masalah penelitian yang ditetapkan sebagai berikut: (a) Bagaimana kualitas informasi (information quality) dari mobile application KAI Access?; (b) Bagaimana kualitas layanan (service quality) dari mobile application KAI Access?; (c) Bagaimana penggunaan (use) dari mobile application KAI Access?; (d) Bagaimana kepuasan pengguna (user satisfaction) dari mobile application KAI Access?

Dengan tujuan penelitian adalah (a) Untuk mengetahui kualitas informasi (information quality) dari mobile application KAI Access; (b) Untuk mengetahui kualitas layanan (service quality) dari mobile application KAI Access; (c) Untuk mengetahuipenggunaan (use) dari mobile application KAI Access; (d) Untuk mengetahuikepuasan pengguna (user satisfaction) dari mobile application KAI Access.

\section{METODE PENELITIAN}

Metode penelitian yang digunakan pada penelitian ini adalah metode kualitatif. Metode kualitatif sebagai prosedur penelitian yang menghasilkan data deskriptif berupa katakata tertulis atau lisan dari orang-orang atau perilaku yang dapat diamati. (J.Moeleong, 2006)

Penelitian diarahkan untuk mendapatkan fakta-fakta yang berhubungan dengan efektivitas penggunaan mobile application KAI Access yang diluncurkan oleh PT Kereta Api Indonesia yang bisa digunakan melalui smartphone yang mempunyai operasi sistem Android dan $\mathrm{iOS}$.

Dalam penelitian ini teknik pengumpulan data yang penulis guanakan adalah wawancara kepada informan kunci yaitu seorang Junior Manager Business Development dari PT Kereta Api Indonesia (Persero) dan lima informan pendukung dari pengguna aplikasi KAI Access serta kuesioner sebagai data tambahan yang diisi oleh 42 responden. Kuesioner digunakan sebagai teknik pengumpulan data yang dilakukan dengan cara memberi seperangkat pertanyaan/ pernyataan tertulis kepada responden untuk dijawabnya.

Teknik analisis data yang digunakan dalam penelitian ini diambil dari Miles dan Huberman (1984) yaitu pengumpulan data (data collection), reduksi data (data reduction), penyajian data (data display), penarikan kesimpulan (conclution verivications) dan evalusi (evaluation).

\section{HASIL DAN PEMBAHASAN}

\section{Objek Penelitian}

Dalam penelitian ini, peneliti berhasil melakukan wawancara secara virtual melalui aplikasi Zoom Meeting dengan informan kunci, yaitu bapak Muhammad Nauval Hidayantho pada tanggal 24 Maret 2021. Beliau adalah seorang junior manager business development dari PT. Kereta Api Indonesia (Persero) yang salah satu tugasnya adalah untuk menangani aplikasi KAI Access.

Selain melakukan wawancara dengan informan kunci, peneliti juga melakukan wawancara secara virtual melalui Zoom Meeting dengan informan pendukung, yaitu dengan lima orang pengguna aplikasi KAI Access yang dipilih secara acak sesuai dengan syarat yang telah ditentukan seperti informan pendukung adalah pengguna aktif aplikasi KAI Access. Ke-lima informan pendukung tersebut adalah ibu Rima Rachmawati, bapak Giri Cahyo Hartono, bapak Muahamad Chaerul Adha, bapak Bayu Himawan dan ibu Resa Putri Rahayu.

\section{Hasil dan Pembahasan Penelitian \\ a. Kualitas Informasi (information quality) dari Mobile Application KAI Access}

(McLean, 1992) kualitas informasi merupakan output yang dihasilkan oleh sistem informasi yang digunakan dan Seddon (1997) menyatakan bahwa kualitas informasi adalah yang dihasilkan oleh sistem informasi akan berpengaruh terhadap persepsi manfaat.

Kualitas informasi adalah informasi yang secara konsisten dapat memenuhi persyaratan dan harapan semua orang yang membutuhkan informasi tersebut untuk melakukan proses mereka. Variable evaluasi ini menggambarkan kualitas informasi yang dipersepsikan oleh pengguna yang diukur dengan keakuratan informasi (accuracy), relevan (relevance), kelengkapan informasi (completeness) dan mudah di mengerti (easy of understanding).

Pada proses penyampaian wawancara yang dilakukan oleh 
peneliti bahwa informasi yang dimuat dalam aplikasi KAI Access diperbaharui secara berkala yang dimana informasi tersebut bisa menjadi lengkap atau completeness karena setiap informasi yang dimuat di aplikasi KAI Access diberikan tanggal update sehingga dapat diketahui bahwa informasi tersebut masih berlaku atau tidaknya.

Meskipun tidak ada jadwal rutin untuk memuat informasi yang ada di aplikasi KAI Access, namun setiap informasi yang dimuat dalam aplikasi KAI Access diambil dari website Kereta Api Indonesia yang dikelola oleh Unit Hubungan Masyarakat PT. Kereta Api Indonesia (Persero).

Didukung dengan data lain yang ditampilkan pada gambar 3.1 bahwa informasi yang didapatkan pengguna pada aplikasi KAI Access sudah terbilang memuaskan dan sesuai dengan apa yang diharapkan. Meskipun ada beberapa hal yang kurang seperti tidak adanya notifikasi dari aplikasi KAI Access tentang adanya informasi terbaru yang berguna untuk memberi tahu pengguna sebagai sarana pemberian informasi yang mudah diakses dan dibaca.

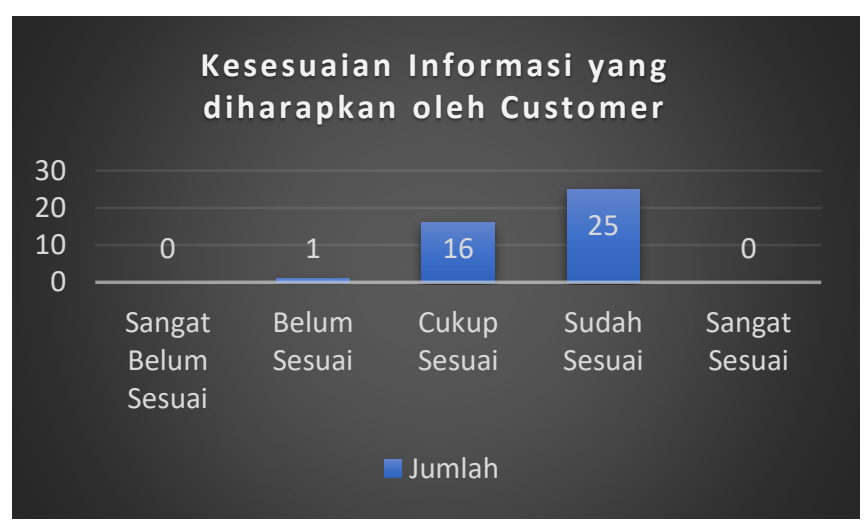

Gambar 3. 1

Kesesuaian Informasi pada Aplikasi KAI Access

Data lain menyebutkan bahwa informasi dari aplikasi KAI Access dari segi pemahaman atau easy of understanding menyatakan semua pengguna paham mengenai informasi yang diberikan pada aplikasi KAI Access. Kejelasan dari informasi yang dimuat di aplikasi KAI Access juga sangat jelas dan akurat serta relevan.

Untuk mendapatkan kemudahan informasi yang didapat juga sangatlah mudah, pengguna tinggal membuka aplikasi KAI Access dan membuka menu informasi yang termuat di aplikasi KAI Access. Pembaharuan informasi menurut pengguna juga sudah cukup baik, karena setiap ada update informasi terbaru mengenai PT. Kereta Api Indonesia (Persero) selalu dimuat kedalam aplikasi KAI Access dengan cepat.

Kepercayaan pengguna terjadi apabila informasi yang diberikan bersifat diperbaharui, konsisten, akurat dan tepat. Peningkatan kepercayaan pemakai sistem informasi, diharapkan akan semakin meningkat kepuasan pengguna terhadap sistem informasi. Maka apabila kepercayaan penggunaan pada sistem informasi tinggi akan mempengaruhi kepuasan penggunanya, maka untuk mengetahui kualitas informasi pada sistem informasi tersebut.
Semua unsur atau indikator yang diteliti dalam variable evaluasi kualitas informasi (information quality) sudah mencangkup semua, seperti keakuratan informasi, relevan, kelengkapan informasi dan pemahamannya mudah dimengerti. Semua indikator yang telah diteliti ini bisa dinyatakan efektif karena telah mencangkup semua indikator yang ada dalam kualitas informasi (information quality).

\section{b. Kualitas Layanan (Service Quality) dari Mobile Application KAI Access}

Kulitas layanan sistem informasi merupakan pelayanan yang didapatkan pengguna dari pengembang informasi, layanan dapat berupa update sistem informasi dan respon dari pengembang jika sistem informasi mengalami masalah. Indikator pengukuran kualitas layanan dari DeLone dan McLean, yaitu daya tanggap atau responsiveness, assurance atau jaminan dan emapti atau emphaty.

Layanan yang diberikan dalam aplikasi KAI Access tidak merubah semua struktur layanan konvensional ke layanan digital, akan tetapi layanan konvensional yang lebih dikurangi. Contohnya seperti layanan konvensional pada pembelian tiket kereta api di stasiun yang customer sendiri harus dating ke stasiun akan tetapi dilayani secara komputerisasi alias digital, maka dari itu layanan konvensional juga bisa disebut dengan layanan semi digital yang mengadopsi layanan konvensional menjadi digital.

Layanan digital yang telah diberikan dari aplikasi KAI Access adalah pemesanan tiket kereta api antar kota, lokal dan kereta api bandara, penambahan tiket dari e-commerce lain, pembatalan serta pengubahan jadwal, Lokomart, berita yang dimuat di aplikasi, metode pembayaran yang beragam dengan cashless, reduksi atau potongan harga bagi pihak terkait serta integrasi antar moda seperti taksi.

Dalam artian, pihak PT. Kereta Api Indonesia (Persero) daya tanggapnya tinggi mengenai kebutuhan pasar untuk menangkap peluang-peluang bisnis yang secara umum hingga saat ini layanan digital telah menjawab semua kebutuhan customer, didukung dengan pihak PT. Kereta Api Indonesia (Persero) telah menganalisa kebutuhan-kebutuhan pasar yang dibutuhkan saat ini.

Dengan mengikuti perkembangan zaman yang sangat cepat, fitur yang saat ini dikembangkan dalam aplikasi KAI Access lebih focus kepada protokol kesahatan untuk menggunakan armada transportasi kereta api seperti pemesanan GeNose C19 dan Rapid Test Antigen yang bisa direservasi melalui aplikasi KAI Access meskipun belum semua stasiun tersedia akan tetapi pengembangan tersebut akan dilakukan dihampir semua stasiun yang ada di Indonesia.

Sebagai implementasi dari indikator pengukuran kualitas layanan yaitu daya tanggap yang tinggi, proses pengaduan dari customer ketika ada sistem eror melalui customer service lewat email ataupun contact center 121, karena khusus pengaduan semua layanan dilakukan secara satu pintu. Pengaduan juga bisa melalui media sosial seperti Instagram dan Twitter yang akan merespon cepat tanggapan dari customer. 
Juga dalam hal perbaikan sistem dari kendala-kendala yang ada, pihak PT. Kereta Api Indonesia (Persero) akan mengumpulkan beberapa kendala tersebut melalui satu pintu lewat contact center, customer service dan juga sosial media serta komentar dari PlayStore dan AppStore mengenai aplikasi KAI Access.

Dalam hal yang telah diuraikan, PT. Kereta Api Indonesia (Persero) telah melakukan empati yang sangat tinggi mengenai masukan-masukan untuk perbaikan kualitas layanan yang saat ini berjalan dengan baik.

Dalam gambar 3.2 mengungkapkan bahwa semua layanan yang dimuat dalam aplikasi KAI Access sangat memudahkan pengguna dan lebih efisien. Dari mulai pemesanan tiket hingga pembayaran serta pembatalan dan perubahan jadwal tiket kereta api pun terbilang mudah dan ringkas. Hanya saja terdapat beberapa kendala yang dihadapi pengguna dalam aplikasi KAI Access, seperti data pribadi yang tidak bisa dirubah terutama Nomor Induk Kependudukan (NIK), terlalu lama melakukan reservasi yang membuat pengguna jenuh karena menunggu dan juga terjadi eror pada aplikasi KAI Access.

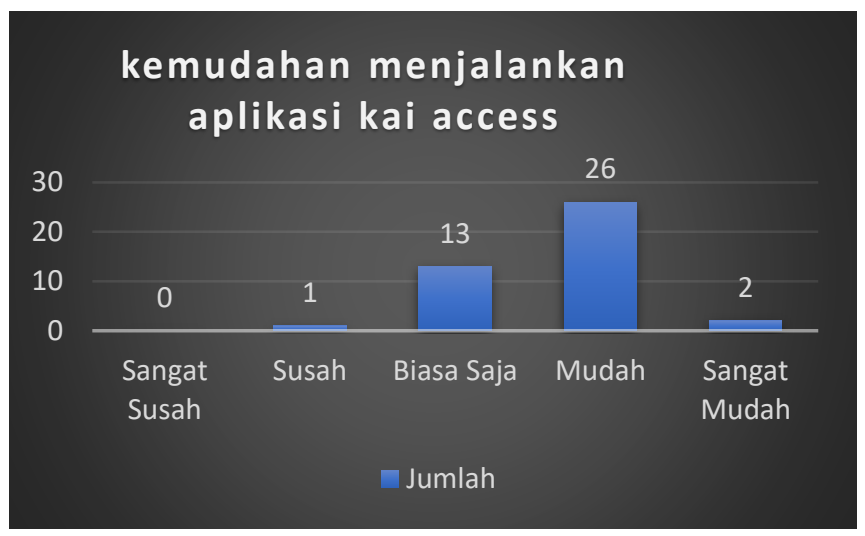

Gambar 3. 2

Kemudahan Menjalankan Aplikasi

Dalam variable evaluasi kualitas layanan (service quality) terdapat beberapa indikator yang telah mencangkup semua penelitian ini dalam indikator kualitas lauanan (service quality) seperti, daya tanggap, jaminan dan empati. Dalam variable evaluasi kualitas layanan (service quality) dapat dinyatakan efektif karena hal tersebut tertuang dalam penemuan dan hasil wawancara yang telah dilakukan.

\section{c. Penggunaan (Use) dari Mobile Application KAI Access}

Penggunaan mengacu pada seberapa sering pengguna memakai sistem informasi. Dalam kaitannya dengan hal ini, penting untuk membedakan apakah pemakaiannya termasuk keharusan atau mandatory yang tidak bisa dihindari atau sukarela (voluntary). Variable evaluasi ini dapat diukur dengan indikator sebagai berikut :

a) Penggunaan sehari-hari (daily use).

b) Frekuensi penggunaan (frequency of use), indikator ini menunjukan seberapa sering pengguna menggunakan sistem informasi tersebut. c) Niat penggunaan (intention to use), niat penggunaan digunakan untuk mengukur pendapat pengguna tentang kegunaan sistem terhadap pekerjaan yang mereka lakukan.

Dalam data yang didapatkan, penggunaan dari aplikasi KAI Access sangatlah terbilang mudah, karena terfokuskan kepada pemesanan tiket kereta api, hanya saja ada penambahan-penambahan fitur yang inovatif. Penggunaan dari aplikasi KAI Access ini tidak dibatasi dalam segi waktu, berarti bisa digunakan sehari-hari dengan melakukan pemesanan tiket baik jarak jauh ataupun kereta api lokal.

Data lain menyebutkan bahwa proses pemesanan tiket kereta api di aplikasi KAI Access lebih efisien dan sangat membantu serta mudah penggunaannya, karena fitur-fitur yang ada dalam aplikasi KAI Access sudah terbilang sangat banyak. Untuk proses pembatalan tiket kereta api di aplikasi KAI Access pun terbilang mudah dengan cara mengisi data pribadi dan nomor rekening pengguna. Rata-rata pengguna melakukan perjalanan dengan kereta api adalah untuk perjalanan bisnis dan untuk pulang kampung serta liburan.

Dalam gambar 3.3 menyebutkan bahwa penggunaan aplikasi KAI Access juga mudah dipahami sehingga bisa dilakukan sehari-hari. Selain untuk memesan tiket kereta api, aplikasi KAI Access juga bisa mengecek jadwal kereta api yang akan ditumpangi.

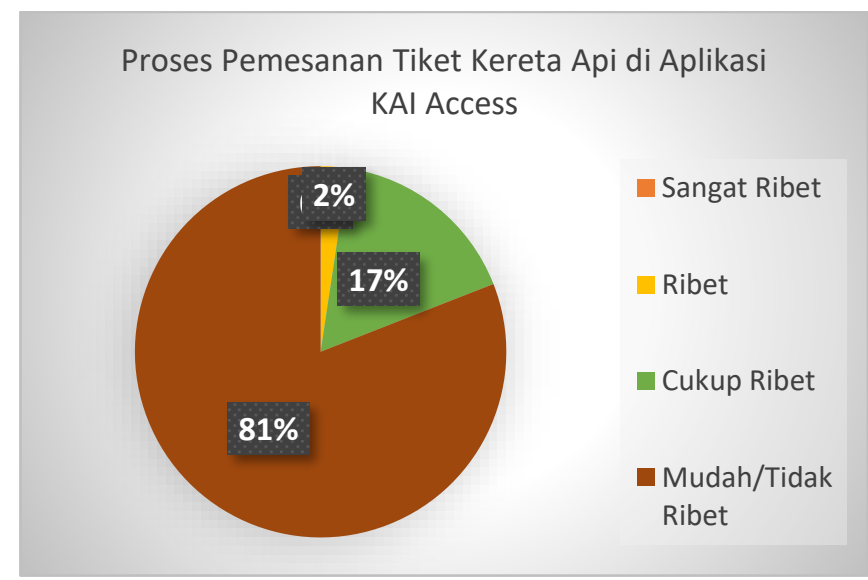

Gambar 3. 3

Kemudahan Layanan Aplikasi

Pengguna juga lebih memilih menggunakan aplikasi KAI Access untuk booking tiket kereta, karena ada beberapa fitur yang tidak ada dalam e-commerce lain, seperti kereta lokal. Kereta lokal juga merupakan salah satu yang diminati oleh pengguna karena harganya yang sangat murah dibandingkan dengan kereta jarak jauh, akan tetapi itu menjadi suatu optional individu tersendiri.

Dalam variable evaluasi penggunaan (use) terdapat indikator seperti penggunaan sehari-hari, frekuensi penggunaan dan niat penggunaan. Indikator yang telah disebutkan ini telah mencangkup semua dalam penelitian dan wawancara yang telah dilakukan, serta bisa dijelaskan bahwa penggunaan aplikasi KAI Access ini telah efektif dan efisien sehingga memudahkan pengguna dalam reservasi tiket kereta api. 


\section{d. Kepuasan Pengguna (User Satisfaction) dari Mobile Application KAI Access}

Kepuasan pengguna merupakan respon dan umpan balik yang dimunculkan pengguna setelah memakai sistem informasi, sikap pengguna terhadap sistem informasi merupakan kriteria subjektif mengenai seberapa puas penggunan terhadap sistem yang digunakan.

Variable evaluasi ini diukur dengan indikator sebagai berikut

a. Efisiensi (efficiency), kepuasan pengguna dapat tercapai jika sistem informasi membantu pekerjaan pengguna secara efisien. Efisien disini dapat dilihat dari sistem informasi yang dapat memberikan solusi terhadap pekerjaan pengguna kaitannya dengan aktivitas pelaporan data secara efisien. Suatu sistem informasi dapat dikatakan efisien jika suatu tujuan yang dimiliki pengguna dapat tercapai dengan melakukan hal yang tepat.

b. Keefektivan (Effectiveness), dapat meningkatkan kepuasan penggunan terhadap sistem informasi tersebut. Keefectivan sistem informasi ini dapat dilihat dari kebutuhan atau tujuan yang dimiliki pengguna dapat tercapai sesuai harapan atau target yang diinginkan.

c. Kepuasan (satisfaction), dapat dikur melalui rasa puas yang dirasakan pengguna dalam menggunakan sistem informasi. Rasa puas pengguna dapat ditimbulkan dari fitur-fitur yang disediakan sistem informasi tersebut. Rasa puas yang dirasakan pengguna mengindikasikan bahwa sistem informasi berhasil memenuhi aspirasi atau kebutuhan pengguan.

Dalam variable ini, variable evaluasi dari kepuasan pelanggan ini hanya dapat diukur oleh customer. Akan tetapi, ada beberapa data mengenai informasi umum yang berkaitan dengan kepuasan pengguna. Informasi umum tersebut untuk memperkuat analisis yang akan dilakukan pada variable evaluasi kepuasan pengguna.

Berdasarkan informasi umum tersebut, hal yang utama adalah sejarah, motivasi, tujuan dan total pengguna dari aplikasi KAI Access. Dalam data, bahwa serah aplikasi KAI Access pertama kali didirikan pada tahun 2011 dengan nama lain Kereta Api Mobile Application atau bisa disebut dengan KABILA yang aplikasi ini hanya berbasis Short Message Service (SMS). Selanjutnya, pada tahun 2013 berganti nama menjadi Keraeta Api Indonesia Official Mobile Application yang berbasis operasi sistem Blackberry. Selanjutnya pada tahun 2014 barulah menjadi nama KAI Access yang bisa diinstal melalui operasi sistem Android dan iOS phone.

Motivasi untuk meluncurkan aplikasi KAI Access adalah memperluas alternative channel teknologi penjualan dengan cara online, jadi customer tidak usah datang langsung ke stasiun untuk memesan tiket kereta. Alasan lainnya adalah sebagai mengikuti perkembangan jaman teknologi saat ini. Tujuannya ialah lebih memudahkan customer melakukan transaksi tanpa harus datang langsung ke stasiun.

Berdasarkan data yang diperoleh dari informan kunci, sampai dengan Februari 2021 untuk register atau pendaftar di aplikasi KAI Access sebanyak 4.968.311 pengguna. Sementara untuk downloder atau installer di operasi sistem Android dan iOS sebanyak 8.753.834 installer.

Aplikasi KAI Access ini dapat menjangkau konsumen lebih luas karena zaman digital. Ditambah dengan kerjasama dengan $e$-commerce lain yang sangat mendukung penjualan tiket kereta api. Bahkan pihak informan kunci mengatakan bahwa tidak takut tersaingi oleh $e$-commerce lainnya, karena muaranya adalah "bagaimana bisa menjual tiket kereta api?" Ya dengan cara berkolaborasi dengan pihak e-commerce lainnya. Berkolaborasi bukan berarti membuka semua hal yang ada di KAI Access, karena KAI Access juga harus ada exclusifitasnya juga, contohnya di e-commerce lain tidak ada fitur untuk pembatalan tiket kereta api. Lebih meniru dari $e$ commerce lain dan menambahkan atau mengurangi fitur yang dianggap penting atau tidak penting.

Aplikasi KAI Access mendorong peningkatan penjualan tiket kereta api, karena hal ini ada kaitannya denga $e$-commerce juga yang bisa membantu menjangkau customer lebih luas artinya bisa meningkatkan jumlah penjualan tiket kereta api juga.

Tidak ada segmen utama untuk aplikasi KAI Access, karena yang diingini adalah aplikasi KAI Access ini mudah digunakan semua pengguna kereta api serta menjangkau semua pengguna kereta api. Akan tetapi dari data yang ada, aplikasi KAI Access di dominasi oleh usia produktif.

Beralih kepada hasil kuesioner dari pengguna mengenai kepuasan pengguna, umumnya customer sudah sangat puas dengan kehadiran aplikasi KAI Access karena semakin mempermudah transaksi yang ada. Seperti transaksi pembayaran melalui $e$-wallet dan QRIS yang sangat dibutuhkan dizaman digitalisasi ini.

Keefektivan dari aplikasi KAI Access juga sudah sangat efektif, karena bisa menghadirkan inovasi-inovasi yang sesuai dengan kebutuhan pada revolusi industri 4.0.

Dari data gambar 3.4 menyebutkan bahwa pengguna sangat puas ketika melakukan pemesanan dan pembatalan tiket kereta di aplikasi KAI Access. Dengan keefektivannya, aplikasi KAI Access bisa menggunakan chek-in secara paperless menggunakan barcode yang terdapat di aplikasi KAI Access. Tidak lupa juga dengan fitur lain yang membuat pengguna merasa puas, seperti tidak adanya biaya administrasi tambahan ketika pembayaran dan pemesanan tiket kereta api melalui aplikasi KAI Access dan proses refund yang mudah. 


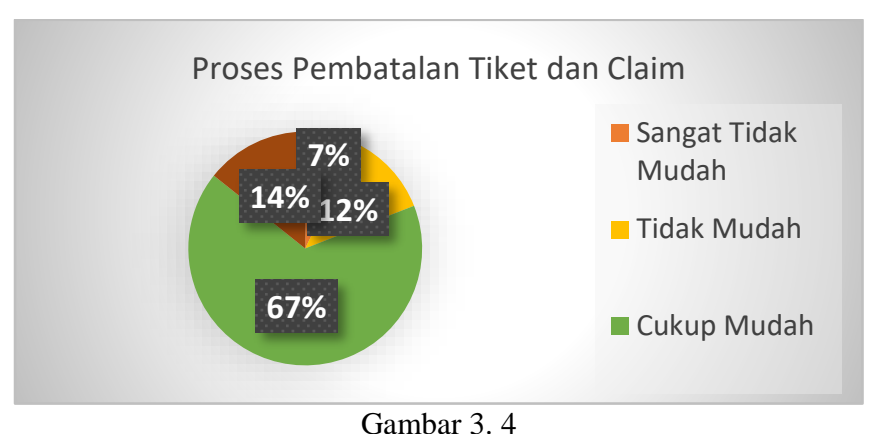

Kemudahan Pembatalan dan Claim

\section{KESIMPULAN}

Berdasarkan hasil penelitian kualitatif dengan teknik observasi, wawancara, dokumentasi dan kuesioner yang telah dilaksanakan mengenai efektivitas penerapan mobile application KAI Access di PT. Kereta Api Indonesia (Persero) dapat diambil beberapa kesimpulan. Kesimpulan tersebut dapat dipaparkan sebagai berikut :

1) Sesuai dengan data yang diperoleh peneliti, bahwa untuk variabel evaluasi kualitas informasi (information quality) dari aplikasi KAI Access sudah mencangkup keempat indikator yang diteliti seperti keakuratan (accuracy) informasinya sudah akurat sesuai dengan kebutuhan pengguna dan juga informasi relevan (relevance), kelengkapan (completeness) dari sisi updating information juga sudah sangat baik, serta yang paling penting adalah mudah dimengerti (easy of understanding) oleh pengguna. Meskipun ada beberapa yang kurang seperti belum adanya notifikasi dari aplikasi untuk memberi tahu ada informasi terbaru serta informasi yang dibutuhkan seperti promo dan diskon yang ada dalam aplikasi KAI Access masih sangat kurang.

2) Untuk variabel evaluasi kualitas layanan (service quality)

\section{DAFTAR PUSTAKA}

\section{Buku:}

Amstrong, K. \&. (2012). Principle of Marketing. New Jersey: Prentice Hall.

Assael, H. (2001). Consumer Behaviour. New York: Thamson.

Donni Juni, A. G. (2013). Manajemen Perkantoran Efektif, Efisien dan Profesional. Bandung: Alfabeta.

Dr. Amir Hamzah, M. (2020). Metode Penelitian Kepustakaan (Library Research). Batu, Malang: Literasi Nusantara.

Gie, L. (2004). Ensiklopedia Administrasi. Jakarta: Gunung Agung.

Hamzah, A. (2020). Metode Penelitian Kepustakaan. Sampang: Literasi Nusantara. dari aplikasi KAI Access sudah mencangkup indikator seperti daya tanggap (responsiveness) dan empati (emphaty). Untuk daya tanggap (responsiveness) dari aplikasi KAI Access sudah memberikan layanan yang jauh lebih baik sesuai dengan kebutuhan konsumen di masa sekarang, serta empati (emphaty) yang baik juga sehingga pihak dari PT. Kereta Api Indonesia (Persero) sangatlah merasakan apa yang dibituhkan oleh konsumen saat ini beserta denga perkembangan zama yang sangat cepat. Meskipun ada beberapa kekurangan seperti terjadinya eror pada aplikasi KAI Access yang memang itu merupakan hal biasa ketika suatu aplikasi perlu adanya perbaikan. Dari situlah bisa dikatakan sangat baik dari kualitas layanan karena pihaknya sendiri memberikan yang terbaik untuk penggunanya.

3) Untuk variable penggunaan (use) dari aplikasi KAI Access, dilihat dari penggunaannya pengguna merupakan kategori sukarela (voluntary) dan keharusan (mandatory), karena dilihat dari data memang sangat beragam. Untuk indikator yang diteliti adalah penggunaan sehari-hari (daily use) sangat dibutuhkan oleh pengguna yang berkaitan langsung dengan indikator frekuensi pengguna (frequency of use) dan niat pengguna (intention of use). Dari data yang didapat disimpulkan bahwa frekuensi penggunaan dari aplikasi KAI Access terbilang sering karena kebutuhan bisnis dan perjalanan dengan keluarga.

4) Dalam variable evaluasi kepuasan pengguna (satisfaction user), aplikasi KAI Access telah sangat baik dengan indikator-indikator yang diteliti seperti efisien (efficiency), keefektivan (effectiveness) dan kepuasam (satisfaction). Dalam data yang didapatkan dapat disimpulkan bahwa semua pengguna mengatakan efisien, efektif dan puas terhadap layanan yang diberikan aplikasi KAI Access.

J.Moeleong, L. (2006). Metodologi Penelitian Kualitatif. Bandung: PT Remaja Rosdakarya.

Keller, K. \&. (2009). Manajemen Pemasaran . In Jilid 1 Edisi 13. Jakarta: Erlangga.

Musafak. (2012). Ekonomi Digital.

Poerwanto, N. (2006). Psikologi Pendidikan. Bandung: PT Remaja Rosdakarya

Siagian, S. P. (2001). Manajemen Sumber Daya Manusia. Jakarta: Bumi Aksara.

Sugiyono. (2005). Memahami Penelitian. Bandung: CV Alfabeta. 
Sugiyono. (2017). Metodelogi Penelitian. Bandung: CV. Alfabeta.

Tanzeh, A. (2006). Dasar-Dasar Penelitian. Surabaya: Elkaf.

Utara, U. S. (2018). Tinjauan Pustaka.

\section{Jurnal:}

Fatkhuroyan. (2012). Kajian Efektivitas Sistem Informasi Jabatan Fungsional Pengamat Meteorologi dan Geofisika : Studi Kasus Badan Meteorologi Klimatologi dan Geofiska . SNATI 2012, B-9.

McLean, W. H. (1992). Psychology and Komputer Science. In Information sistem success: the quest for the dependent variable. Inf. Syst. Rest.
Wajong, Y. (2005). Fungsi Administrasi Negara. Jakarta: Djambatan.

Y., W. (2005). Fungsi Administrasi Negara. Djakarta.

Zed, M. (2008). Metode Penelitian Kepustakaan. Jakarta: Yayaysan Obor Indonesia.

Setiawan, D. (2018, April 1). Dampak Perkembangan Teknologi Komunikasi dan Informasi terhadap Budaya. Retrieved from Jurnal Simbolika: https://www.researchgate.net/publication/3 26036329_Dampak_Perkembangan_Tekn ologi_Informasi_dan_Komunikasi_Terhad ap_Budaya

W Chin, T. P. (1995). On the Use, Usefulness, and Easy of Use of Structural Equation Modeling in MIS Research : A Note of Caution. Journal of Management Information Sistem Quarterly, Vol 9 No.5.

Nasional.kompas.com. (2020, 08 12). Data Penduduk Indonesia Tahun 2020. Retrieved from https://nasional.kompas.com/read/2020/08/ 12/15261351/data-kependudukan-2020penduduk-indonesia-268583016jiwa?page=all

Putri, A. S. (2020, September 10). Retrieved from Pengertian Teknologi Informasi dan Komunikasi:

https://www.kompas.com/skola/read/2020/ 09/10/194000969/pengertian-teknologiinformasi-dan-komunikasi-tik-dancontohnya?page $=$ all https://tekno.kompas.com/read/2018/11/27 /15170027/2025-ekonomi-digitalindonesia-diprediksi-bernilai-rp-1.400triliun?page $=$ all 


\section{Situs Internet:}

Fanani, A. (2015, Februari). 4 Era Perkembangan Teknologi Komputer. Retrieved from https://slideplayer.info/slide/2671310/

kai.id. (n.d.). Sekilas Tentang Kereta Api Indonesia. Retrieved from https://www.kai.id/corporate/about_kai/

Lazuardi, Y. (2017, Maret 31). Apakah Kamu Salah Satu Faktor Penyebab Pesatnya Pertumbuhan Internet di Indonesia? Retrieved from https://www.exabytes.co.id/blog/apakahkamu-salah-satu-faktor-penyebabpesatnya-pertumbuhan-internet-diindonesia/

Maxmanroe.com. (2018, Nov 07). Aspek-aspek Efektivitas. Retrieved from

\section{Skripsi}

Prasetyo, T. A. (2015). Analisis Pengaruh Kualitas Produk, Kualitas Layanan, Harga dan Lokasi terhadap Pengambilan Keputusan Pembelian. FEB UNDIP Semarang.

Putra, M. N. (2018). PENGARUH KEPERCAYAAN, KUALITAS https://www.maxmanroe.com/vid/manaje $\mathrm{men} /$ pengertian-efektivitas.html

Maxmanroe.com. (2018, Nov 07). Kriteria Efektivitas. Retrieved from https://www.maxmanroe.com/vid/manaje men/pengertian-efektivitas.html

Universitas Brawijaya. (2014, Mei 26). Kepuasan Pelanggan. Retrieved from Muwafik Center http://muwafikcenter.lecture.ub.ac.id/2014/ 05/psc-kepuasan-pelanggan/

UNIKOM. (n.d.). Metodelogi Penelitian. Retrieved from https://elib.unikom.ac.id/files/disk1/725/jb ptunikompp-gdl-utaradevip-36239-3unikom_u-i.pdf

INFORMASI, DAN PERSEPSI RISIKO TERHADAP KEPUTUSAN PEMBELIAN (STUDI KASUS PADA PELANGGAN ONLINE SHOP SHOPEE DI KOTA YOGYAKARTA). . FE UII Yogyakarta. 